\title{
Differential Expression of Pancreatitis-Associated Protein and Thrombospondins in Arterial versus Venous Tissues
}

\author{
Theodora Szasz $^{\mathrm{a}}$ Susan Eddy ${ }^{\mathrm{b}}$ Joseph Paulauskis ${ }^{\mathrm{b}}$ Robert Burnett ${ }^{\mathrm{a}}$ \\ Merete Ellekilde $^{a}$ Juan L. Iovanna ${ }^{c}$ Stephanie W. Watts ${ }^{a}$ \\ a Department of Pharmacology and Toxicology, Michigan State University, East Lansing, Mich., and \\ ${ }^{b}$ Pfizer Global Research and Development, Groton, Conn., USA; ' INSERM U.624, Stress Cellulaire, Marseille, France
}

\section{Key Words}

Veins $\cdot$ Arteries $\cdot$ Gene expression $\cdot$ Inflammation

\begin{abstract}
Background/Aims: Arteries and veins modulate cardiovascular homeostasis and contribute to hypertension pathogenesis. Functional differences between arteries and veins are based upon differences in gene expression. To better characterize these expression patterns, and to identify candidate genes that could be manipulated selectively in the venous system, we performed whole genome expression profiling of arteries and veins. Methods: We used the CodeLink platform and the major artery (thoracic aorta) and vein (caudal vena cava) of the rat. Results: The most prominent difference was pancreatitis-associated protein (PAP1), expressed 64-fold higher in vena cava versus aorta. Expression of mRNA for thrombospondins (TSP-1, TSP-4) was greater than 5 -fold higher in veins versus arteries. Higher mRNA expression of TSP-1, TSP-2, TSP-4 and PAP1 in vena cava versus aorta was confirmed by PCR. Immunohistochemical analysis of tissue sections qualitatively confirmed a higher expression of these proteins in vena cava versus aorta. Conclusion: This is the first gene array study of adult rat arterial and venous tissues, and also the first study to report differences in inflammatory genes between arteries and veins.
\end{abstract}

\section{KARGER}

() 2009 S. Karger AG, Base

Fax +41613061234

E-Mail karger@karger.ch

www.karger.com
Accessible online at: www.karger.com/jvr
Data from these studies may provide novel insights into the genetic basis for functional differences between arteries and veins in health and disease.

Copyright $\odot 2009$ S. Karger AG, Basel

\section{Introduction}

Hypertension remains a disease that afflicts a significant portion of our adult population and is now understood to be less controlled than desirable [1]. This lack of control renders an individual more susceptible to coronary arterial disease, heart failure and renal insufficiency. Because of the large number of uncontrolled patients, new therapies with reduced side effects and/or alternative targets would be beneficial. Presently, the arterial circulation remains a steadfast target of antihypertensive medications such as calcium channel blockers, angiotensinconverting enzyme inhibitors and angiotensin receptor blockers. Elevated total peripheral resistance, as determined by small arteries and arterioles, plays an uncontested role in hypertension. However, recent evidence suggests that the venous circulation and elevations in venomotor tone may also contribute to hypertension.

Unlike arteries, veins serve a capacitance function in the body, providing a reservoir of blood. Increases in 

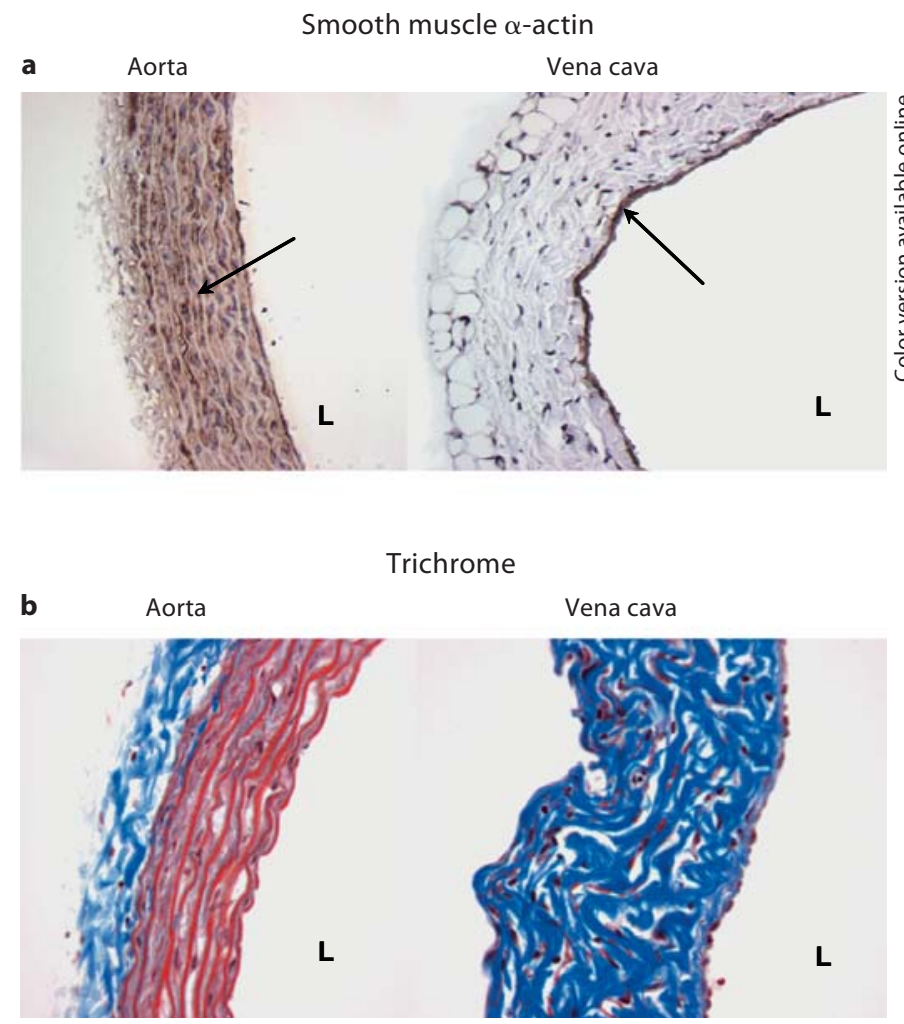

Fig. 1. A basic comparison of the architecture of the aorta (left) and vena cava (right). a Immunohistochemical staining for smooth muscle $\alpha$-actin is shown as a dark precipitate. b Masson trichrome staining. Representative of 4 different pairs of tissues. $\mathrm{L}=$ Lumen of the vessel.

mean circulatory filling pressure (an index of venomotor tone independent of cardiac filling) occur early in the course of hypertension in some experimental models, and do so without an increase in total blood volume, suggesting elevations in venomotor tone [2-4]. The resultant decrease in vascular compliance is most marked in the extrathoracic veins $[5,6]$, and is particularly notable in the splanchnic circulation [7]. The consequence of reduced vascular capacitance is a shift of blood from the veins of the abdomen and extremities (the peripheral compartment) into the thorax (the central compartment). Just such a 'central' redistribution of blood volume has been found during the developing phase of essential hypertension in humans [8-10]. Changes in venomotor tone as a cause of hypertension are understudied.

It would be ideal to stimulate or inhibit the venous circulation selectively to alter the contribution of venomotor tone to blood pressure regulation. However, we have been unable to identify pharmacological compounds that selectively activate or inhibit venous smooth muscle tone. The lack of available tools exists in part because we do not currently understand basic differences in gene/protein expression in adult arteries and veins. Here, we present data from gene array experiments performed in the hopes that we could identify genes that might be selectively modified in the venous circulation. Differences in genetic programming in the developing circulatory systems have been identified, with the ephrin, Notch and neuropilin proteins defining arterial versus venous circulation [11-19]. It is unknown whether these differences remain faithful through adulthood. Because these proteins also play a role in neuron axonal guidance, their use as selective modifiers of the circulatory system is limited. We set out to identify differences in gene expression between the vena cava and aorta of the adult animal, with the hypothesis that there are genes selectively expressed in the normal adult vein compared to the artery.

We chose to use the thoracic aorta and vena cava as our model artery and vein. These are similarly sized vessels (diameter based) and derive from a similar body compartment (thorax). We used the whole blood vessel in these experiments, including the intimal endothelial cell layer, media and adventitia. The purpose in doing so is that all cell layers are appreciably involved in the overall function of a blood vessel, and we do not yet understand the function of the highly complex and extensive adventitia of the vena cava (fig. 1). A CodeLink-based gene array was performed on 6 pairs of arteries and veins, each from a different animal, and selected findings were confirmed with real-time PCR as well as immunohistochemistry. Our results identified a profile of a vein that was unexpected. Specifically, venous tissue expressed genes of anti-inflammatory/anti-apoptotic proteins. These findings are provocative in the insight they give to potential differences in arterial versus venous roles in inflammation-dependent cardiovascular diseases.

\section{Methods}

\section{Animal Use}

Male Sprague-Dawley rats (250 g; Charles River, Indianapolis, Ind., USA) were used. All protocols were approved by the Michigan State University Institutional Animal Care and Use Committee. Animals were deeply anesthetized with sodium pentobarbital (60$80 \mathrm{mg} / \mathrm{kg}$, intraperitoneally), and aorta as well as vena cava were removed. Tissues were cleaned of adherent fat and connective tissue, and then taken through one of the following experimental protocols. 
Gene Array Protocol

RNA Isolation

Total RNA was isolated from approximately 10 -mg sections of rat aorta and vena cava using the MELT ${ }^{\mathrm{TM}}$ Total RNA Isolation System (Ambion/Applied Biosystems, Austin, Tex., USA) according to the manufacturer's protocol. RNA was then quantified on a NanoDrop spectrophotometer (NanoDrop Technologies/Thermo Fisher Scientific, Wilmington, Del., USA).

\section{Microarrays}

CodeLink $^{\mathrm{TM}}$ Rat Whole Genome Bioarrays (Amersham/GE Healthcare, Piscataway, N.J., USA) were used according to the manufacturer's protocol. Briefly, first-strand cDNA was synthesized starting with $1 \mu \mathrm{g}$ DNase-treated total RNA from each sample and diluted bacterial mRNA controls. After second-strand synthesis and cDNA purification, cRNA was in vitro transcribed with incorporation of biotin-labeled UTP, purified and assessed for concentration, purity and quality. Ten micrograms of cRNA were then fragmented and hybridized to arrays. Streptavidin-Cy5 conjugate was used for detection. Arrays were scanned using the GenePix Array Scanner (Axon Instruments/Molecular Devices, Sunnyvale, Calif., USA).

\section{Data Aquiring and Processing}

Images were acquired using GenePix Pro 6.0 software (Axon Instruments/Molecular Devices), which runs automatic spotfinding algorithms, subtracts background, filters absent and flags low (near background), saturated, noisy or otherwise poor quality spots. Raw intensities of the approximately 34,000 spots on each array ( 6 for aorta, 6 for vena cava) were median normalized as a batch. Normalized intensity values of each spot were averaged and $p$ values were calculated in Microsoft Excel. These data were then uploaded into Gene Sifter (VizX Labs, Seattle, Wash., USA) where gene expression probe names were identified and differentially expressed genes (fold threshold $=5$ ) were displayed and further analyzed.

\section{RT-PCR Protocol}

One microgram DNase-treated total RNA was reverse transcribed to first-strand cDNA using an oligo $(\mathrm{dT})_{12-18}$ primer, dNTP mix and Superscript II reverse transcriptase (Invitrogen, Carlsbad, Calif., USA) according to the manufacturer's protocol. RT-PCR was performed with equal amounts of cDNA from each sample using the SYBR Green PCR Master Mix (Applied Biosystems, Foster City, Calif., USA) on a Real Time 7500 PCR System (Applied Biosystems). Primers for PAP1 (NM_053289), synthesized at the Macromolecular Structure, Sequencing and Synthesis Facility at MSU, were designed using the Primer3 software (Whitehead Institute, Cambridge, Md., USA) [20]: PAP1-L: TGGGAGAGGAACCCATCTACT; PAP1-R: CGTAGGGCAACTTCACTTCA. TSP-1 (NM_001013062.1), TSP-2 (XM_ 214778.4), TSP-4 (XM_342172.3) and $\beta-2$ microglobulin (NM 012512) were purchased from SuperArray (Frederick, Md., USA) and their sequences are not published. Quantification of PAP1, TSP1, TSP-2 and TSP-4 expression was performed relative to $\beta-2$ microglobulin, a housekeeping gene that in pilot experiments had the most uniform expression in our tissues. Data are reported as mean \pm SEM of $2^{-\Delta C t}$ values relative to $\beta-2$ microglobulin.
Immunohistochemical Protocol

Thoracic aorta and vena cava were cleaned and formaldehyde fixed. Paraffin-embedded sections $(8 \mu \mathrm{m})$ were cut, dewaxed, antigen retrieved and taken through a standard protocol using a Vector kit (Vector Laboratories, Burlingame, Calif., USA). Tissue sections were incubated $24 \mathrm{~h}$ with primary antibody $(1-5 \mu \mathrm{g} / \mathrm{ml})$, antibody quenched with $5 \times$ competing peptide when competing peptide was available, or no primary antibody. Sections of the small intestine and human bone marrow (megakaryocytes) were used as a positive control for PAP1 and the TSP family. The same concentration of primary and secondary antibody was used on positive control/aortic/vena cava sections. Sections were developed according to manufacturer's instructions using a DAB developing solution (Vector Laboratories). Binding was observed as a dark brown/black precipitate. All slides were counterstained with Vector hematoxylin for $30 \mathrm{~s}$, with nuclei stained blue. Sections were dried, cover slipped and photographed on a Nikon TE2000 inverted microscope using MetaMorph ${ }^{\circledR}$ software. Photographs are shown at $40 \times$ magnification.

PAP1 antibodies were purchased from R\&D Systems (anti-rat Reg2/Pap MAB 1996) or provided by Dr. Juan Iovanna. Antibodies against TSP family members were as follows: TSP-1 (collagen type V binding domain, clone A6.1; Thermo Scientific, Fremont, Calif., USA), TSP-2 (N-terminus, sc-12313; Santa Cruz Biotechnology, Santa Cruz, Calif., USA) and TSP-4 (C-terminus, sc-7657; Santa Cruz Biotechnology).

\section{Results}

Figure 1a depicts immunohistochemical staining of the aorta (left) and vena cava (right) with an antibody directed against smooth muscle $\alpha$-actin. While the aorta possesses at least 8 identifiable layers of smooth muscle between the white elastin cables, vena cava possesses but one layer that directly underlies the endothelial layer. The remainder of the vena cava stains for collagen, as shown in blue as a part of Masson trichrome staining in figure $1 b$. The adventitial layer is significantly more pronounced in the vena cava compared to the aorta, but adventitia is present in both vessel types.

\section{Gene Array}

The data discussed in this publication have been deposited in NCBI's Gene Expression Omnibus [21] and are accessible through GEO Series accession number GSE12255 (http://www.ncbi.nlm.nih.gov/geo/query/acc. cgi?acc $=$ GSE12255). Table 1 details those genes that were expressed either 5 -fold higher or lower in the vena cava versus the aorta. Of all genes, the greatest differences in mRNA expression were observed for PAP1, a gene with anti-inflammatory functions. A related peptide, PAP3, was also more highly expressed in the vena cava versus the aorta. Another significant finding was the higher ex- 
Table 1. Genes expressed at least 5-fold differently in the normal rat aorta versus vena cava

Aortic Vena cava expression expression

Vena cava expression > aorta expression

$\begin{array}{lll}\text { PAP1 } & 0.7 & 73\end{array}$

PAP3

Myosin light chain, pt 7

Myosin-binding protein

Anterior gradient 2

Troponin 1, type 3

Myozenin 2

Sarcolipin

Chemokine ligand 19

Pancreatic secretory trypsin inhibitor type II 0.4

Cytochrome c oxidase, subunit VIa, polypeptide 2

Small muscle protein X-linked

Titin

Myosin-binding protein, cardiac

Brevican core protein

Actinin $\alpha 2$

Actin, $\alpha$ cardiac 1

WDNMI-like

Obscurin

Mesothelin

TSP-1

Tbox 5

Troponin C type 1

Ras-like E2 inhib Or inhibitor

Uroplakin 1B

Troponin T2, cardiac

Adrenomedullin receptor

Oncopt Ind TCPT homolog

Leucine repeat count 10

ASIC 1B

Prepronociceptin

F-spondin

Wilms tumor 1

Glycoprotein m6a

TSP-4

Transthyretin

Myosin-binding protein C, slow

Keratin 19, complex, acidic

Aorta expression > vena cava expression

Sphingomyelin PDE3, neutral

Cytokine-like protein C-17

Gap junction $\alpha 5$

P2X receptor

Protease inhibitor 16

Frizzled related protein

Major urinary protein 5

Cardiomyopathy-associated protein

Dentin matrix protein 1

Threshold $=5$; quality $=0.5$. Numbers represent the averaged $(n=6)$ normalized intensity for the genes listed in the first column, ordered by the fold difference. Genes that have been chosen for RTPCR verification and protein expression follow-up experiments are set in bold. pression of two of the thrombospondins (TSP-1 and TSP4 ) in vena cava versus the aorta. The transcript levels for $\mathrm{PAP}$, as the highest difference in gene expression in favor of venous transcript, and TSPs (TSP-1, TSP-4 and additionally TSP-2, another TSP family member), as a family of anti-inflammatory/anti-angiogenic genes, were next validated using RT-PCR.

\section{RT-PCR Validation and Immunohistochemistry.}

Real-time RT-PCR of RNA isolated from vena cava and aorta was performed to validate gene array findings. Figures $2 \mathrm{a}$ to $5 \mathrm{a}$ display results from real-time RT-PCR demonstrating that the mRNA expression of PAP1, TSP1 , TSP-2 and TSP- 4 was significantly greater $(\mathrm{p}<0.05)$ in the vena cava versus the aorta.

Immunohistochemistry using antibodies raised towards rat PAP1 and TSPs were used to determine the relative quantity and site of protein expression in arteries versus veins.

\section{PAP1}

PAP1 antibody was first used in the intestine as a positive control, as PAP1 is robustly expressed in this tissue. PAP1 was stained for intensely in the intestine (fig. 2b). PAP1 expression was observed throughout the vena cava layers with significant staining in the adventitia, and only modest staining in the adventitia of the aorta. A competing peptide was not available. Similar results were observed using either the R\&D antibody or Rat-1 antibody raised by Dr. Iovanna.

\section{TSP-1}

TSP-1 antibody recognized megakaryocytes in bone marrow, validating the usefulness of this antibody. Staining for TSP-1 was present in the vena cava (compare fig. $3 \mathrm{~b}$ with and without primary antibody) but not identifiable in the aorta, even in the adventitia. A competing peptide was not used, as staining was faint.

\section{TSP-2}

Staining for TSP-2 was substantially stronger compared to TSP-1 in both blood vessels, while that in the bone marrow was expectedly positive (fig. 4). The vena cava showed staining that suggests a more robust expression of TSP-2 compared to aorta, with the competing peptide significantly reducing TSP-2 antibody staining. TSP-2 staining in the vena cava was strongest in the layers nearest the lumen of the vessel, and weakly observed in smooth muscle layers of the aorta. 


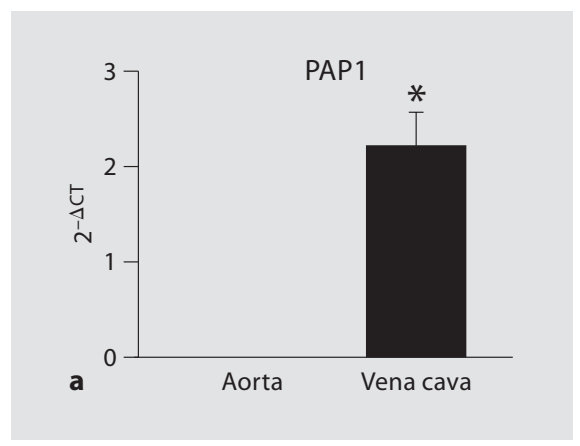

Fig. 2. a PAP1 mRNA expression quantified by real-time RT-PCR. ${ }^{*} \mathrm{p}<0.05$ between aorta and vena cava $(n=4)$. b Immunohistochemical expression of PAP1 in normal aorta and vena cava tissues. The small intestine was used as a positive control for PAP1 expression. Positive staining is observed as dark precipitate, and the nuclei are counterstained by hematoxylin. $\mathrm{L}=$ Lumen of the vessel. Representative of 6 different pairs of tissues.

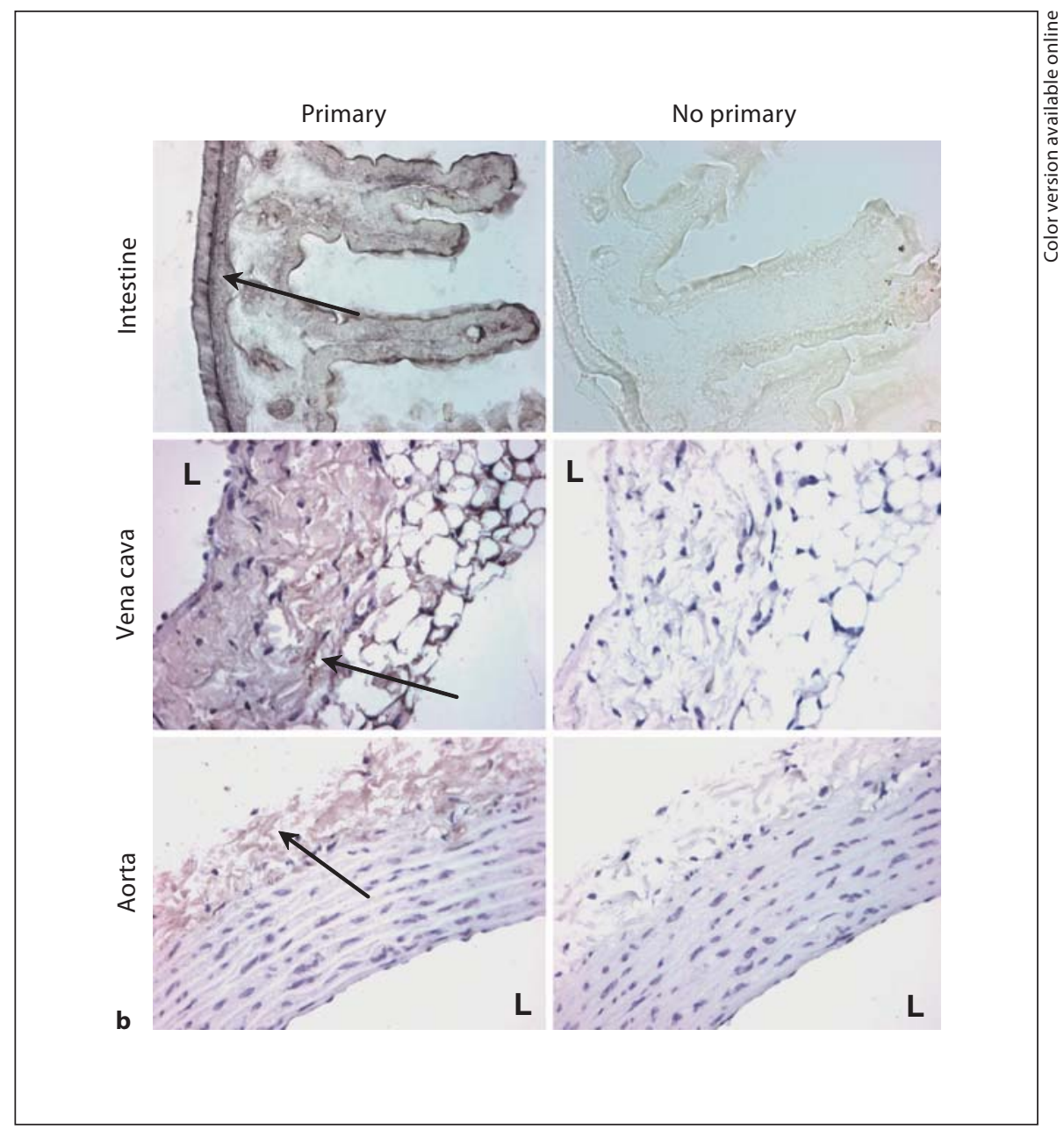

\section{TSP-4}

TSP-4 protein was observed in both aorta and vena cava, though specific staining was qualitatively greater in the vena cava compared to aorta (fig. 5). Staining in the adventitia of the aorta was not specific, while staining occurred throughout the vena cava. Importantly, the TSP-4 antibody positively stained bone marrow sections.

\section{Discussion}

We undertook this study to determine whether genes might be selectively expressed in the adult rat vena cava compared to the aorta. Multiple differences were observed, the most intriguing of which was a higher venous expression of genes for proteins that possess anti-inflammatory, anti-apoptotic and/or anti-angiogenic properties. The most prominent difference was for PAP1.

Arterial versus Venous PAP/TSP

Expression

\section{PAP1 and TSPs}

PAP is a lectin-related secretory protein present in low levels in normal pancreas but highly expressed and secreted in the acute phase of pancreatitis [22]. PAP has most recently been described as an anti-inflammatory cytokine in in vitro and in vivo experiments [23-26]. In the gene array and in confirmatory RT-PCR, PAP1 expression was significantly higher in the vena cava compared to the aorta. Similarly, mRNA for TSP-1 and TSP-4 were 5- to 8-fold more highly expressed in veins compared to arteries, and this was confirmed in PCR. TSPs, in particular TSP-1, are stored in platelet $\alpha$-granules, and are a constitutive component of epithelial and endothelial basement membranes [27, 28]. TSP-1 was the first endogenous inhibitor of angiogenesis discovered [29], and TSP-2 has similar anti-angiogenic properties [27]. TSPs have a host of additional functions that contribute to a generally protective or anti-inflammatory profile [30- 
Fig. 3. a TSP-1 mRNA expression quantified by real-time RT-PCR. ${ }^{*} p<0.05$ between aorta and vena cava $(n=4)$. b Immunohistochemical expression of TSP-1 in normal aorta and vena cava tissues. Normal bone marrow was used as a positive control for TSP1 expression. Positive staining is observed as dark precipitate, and the nuclei are counterstained by hematoxylin. $\mathrm{L}=$ Lumen of the vessel. Representative of 6 different pairs of tissues.
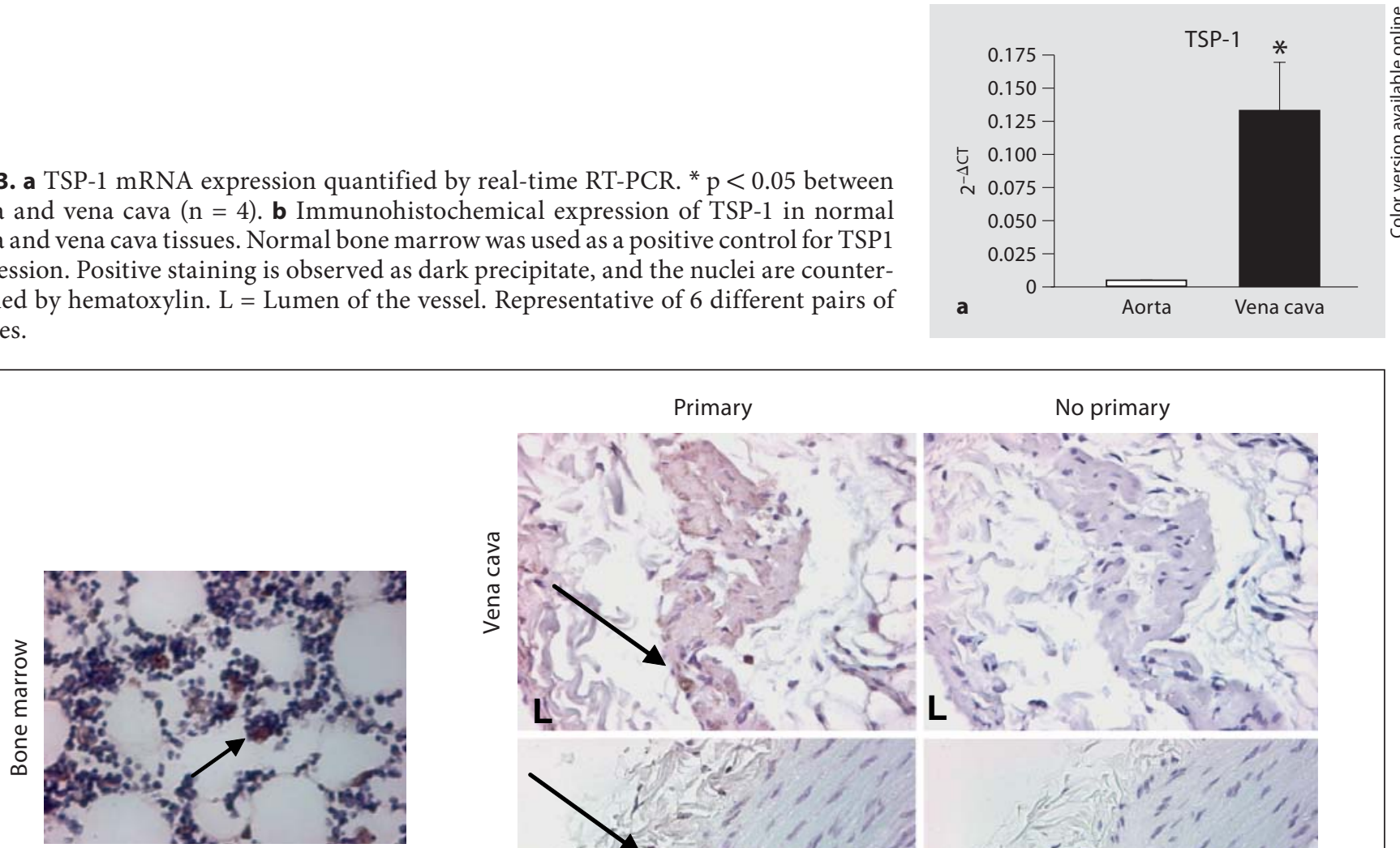

b

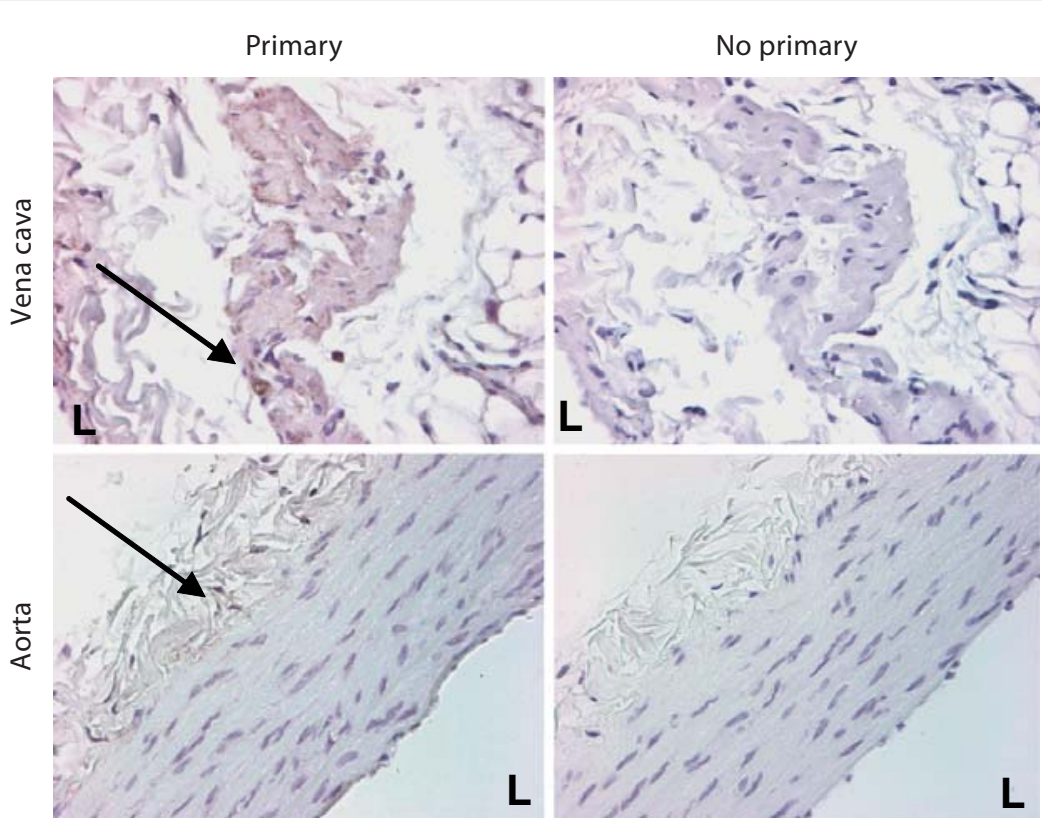

37]. Thus, it appears that the anti-inflammatory and antiapoptotic properties of veins might be naturally enhanced compared to arteries. The qualitative immunohistochemical studies performed here do not enable us to ascribe the differences in PAP and TSP to a specific cell type. However, as adventitia is present to a much higher degree in the vena cava compared to the aorta, we might speculate that cells from this layer, such as fibroblasts, may account for these differences. We especially cannot exclude this possibility in the case of TSPs, given their complex roles and interactions in the extracellular matrix [27].

\section{Concurrence with Other Gene Array Studies}

A few studies have addressed the basic question asked presently, but with some important differences. In 2000, Adams et al. [38] compared the macaque aorta and vena cava using a cDNA array with human genes. Sixty-eight genes were elevated in the aorta versus the vena cava, with the greatest difference being observed for the regulator of G protein signaling RGS5. PAP1 and the TSPs were not discussed. Shin and Anderson [39] performed subtractive hybridization for arterial-specific genes in endothelial cells from mouse E11 embryos. Using this approach, they did not identify any venous-specific gene. More recently, Deng et al. [40, 41] have compared cultured human saphenous vein smooth muscle or endothelial cell to the cultured coronary artery smooth muscle cell or endothelial cell. These are important tissues because of the use of the saphenous vein in replacing coronary artery segments in bypass surgery. It has been noted for some time that atherosclerosis predominantly affects arteries but minimally affects veins. Differences in endothelial cell expression were observed, and TSP-2 was more highly 
Fig. 4. a TSP-2 mRNA expression quantified by real-time RT-PCR. ${ }^{*} \mathrm{p}<0.05$ between aorta and vena cava $(n=4)$. b Immunohistochemical expression of TSP-2 in normal aorta and vena cava tissues. Normal bone marrow was used as a positive control for TSP2 expression. Positive staining is observed as dark precipitate, and the nuclei are counterstained by hematoxylin. $\mathrm{L}=$ Lumen of the vessel. Representative of 6 different pairs of tissues.
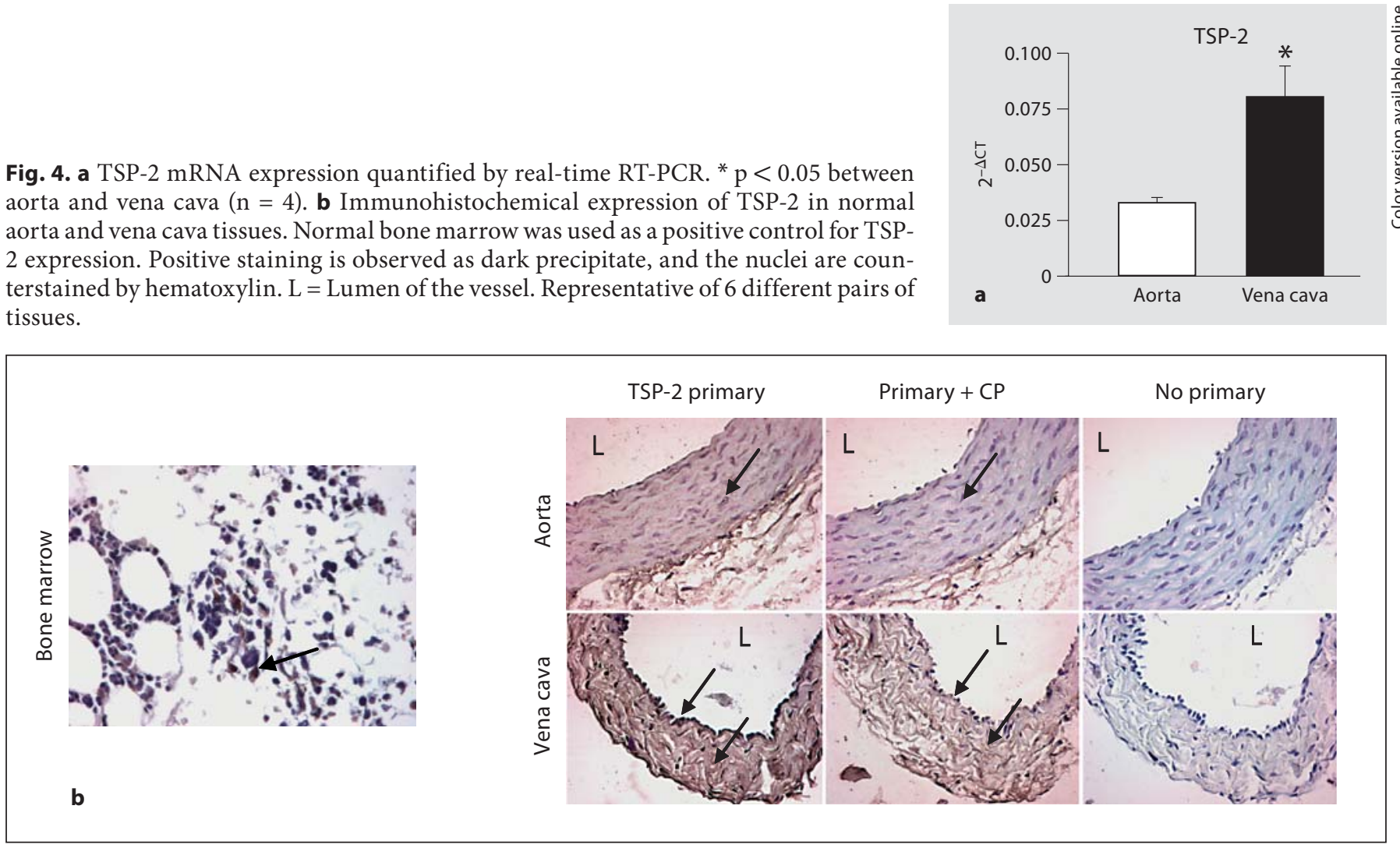

Fig. 5. a TSP-4 mRNA expression quantified by real-time RT-PCR. * $\mathrm{p}<0.05$ between aorta and vena cava $(n=4)$. $\mathbf{b}$ Immunohistochemical expression of TSP-4 in normal aorta and vena cava tissues. Normal bone marrow was used as a positive control for TSP4 expression. Positive staining is observed as dark precipitate, and the nuclei are counterstained by hematoxylin. $\mathrm{L}=$ Lumen of the vessel. Representative of 6 different pairs of tissues.
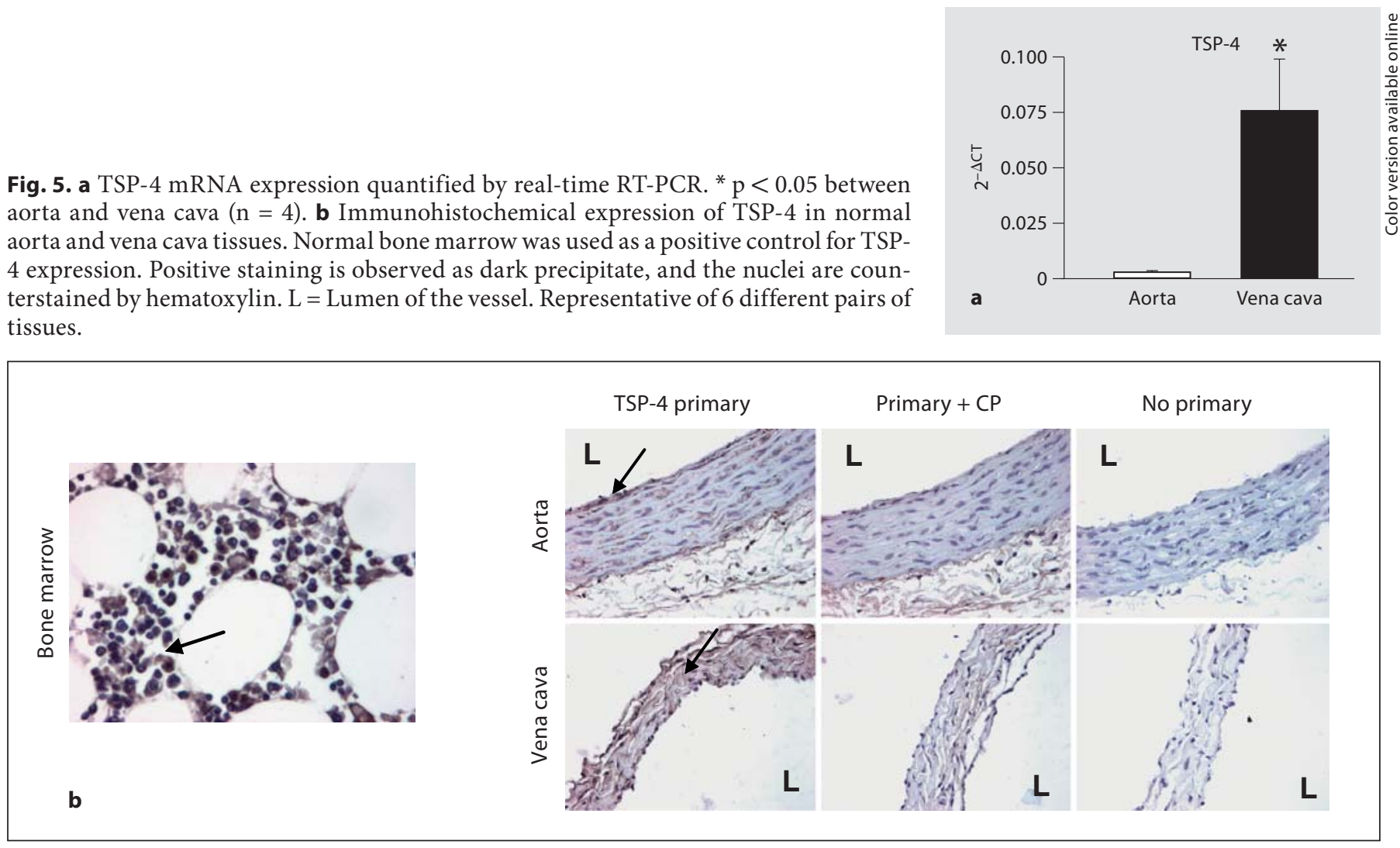

Arterial versus Venous PAP/TSP

J Vasc Res 2009;46:551-560 
expressed in the venous endothelial cell versus the arterial endothelial cells. Interestingly, they observed an increase in cytochrome c oxidase subunit via polypeptide 2 in venous endothelial cells compared to arterial endothelial cells, an increase we also found in the whole tissue (table 1). In the smooth muscle cultures of these vessels, TSP repeat containing 1 protein and decorin were more highly expressed in the venous versus arterial smooth muscle cells. TSP-1 expression, however, was higher in the aortic versus venous cultured smooth muscle cells.

A recent report suggests a prothrombotic gene expression in vascular smooth muscle cells from the human saphenous vein but not internal mammary artery [42]. However, cells from these studies and those by Deng et al. $[40,41]$ were cultured and thus their phenotype is not a basal one. One study has used arteries and veins from the rat, as we have presently, but only for a small-scale gene expression comparison [43]. These authors used small vessels from the rat mesentery in duplex RT-PCR to measure vascular endothelial growth factor, TIE2, angiopoietin-2 and a disintegrin-like and metalloprotease with TSP motifs-1 (ADAMTS1). In all cases but ADAMTS1, expression of the markers was higher in the arteries versus the veins. In our hands, ADAMTS1 was somewhat lower in vena cava versus aorta (2.12-fold lower). Our studies differ from previous ones in our use of the naïve, uncultured tissue of the adult rat as a source for RNA profiled in gene array.

\section{Inflammation in Venous Tissue in Cardiovascular \\ Disease}

Arterial inflammation in cardiovascular disease, particularly in hypertension and atherosclerosis, is well established. Inflammatory endpoints include elevated arterial concentrations of pro-inflammatory interleukins, intercellular adhesion molecule-1, vascular cell adhesion molecular, selectins, monocyte chemoattractant protein1 , as well as infiltration of immune cells [44-47] and the more distal endpoints of arterial remodeling and fibrosis. By contrast, little is known as to whether or how the venous system becomes similarly inflamed in hypertension. Venous endothelium may inherently respond differently to inflammation. A study that investigated monocyte adhesion in human arterial versus venous endothelial cells found differential expression of endothelial cell adhesion molecules (vascular cell adhesion molecular, intercellular adhesion molecule and E-selectin) as well as differences in monocyte adhesion in response to inflammatory stimuli [48]. In this study, venous endothelial cells appeared more sensitive to these stimuli, pre- sumably due to differences in NF- $\mathrm{BB}$ signaling. Leukocyte adhesion was also compared in another study that excluded the role of different hemodynamic factors in the preferential neutrophil rolling on mesenteric venular versus arteriolar endothelium [49]. Similarly, the different solute barrier properties of arterial and venous endothelium was found to be correlated with differences in the expression of junctional proteins [50]. Therefore, if indeed veins have more anti-inflammatory properties compared to arteries, as our study suggests, these differences may not be originating in the endothelium, but rather the smooth muscle or adventitial layers. We have previously observed that vena cava do not display the vascular remodeling classically observed in arteries from a mineralocorticoid-based model of hypertension [51]. This finding differs somewhat from small venules and venous valves in which remodeling was observed; these valves are absent in the large-sized vena cava [52-56]. Neutrophil infiltration of veins can also occur, but in venous hypertension [57]. Atherosclerotic lesions in venous bypass segments placed in an arterial/high-pressure setting occur and this process is undoubtedly inflammatory [58, 59]. However, this is not the normal physiological situation for a vein, as a vein functions at significantly lower pressure. Veins do not typically develop atherosclerosis. Though the lower pressure to which they are exposed may be one factor in the difference of vessel predisposition to atherosclerosis, this does not explain why veins are resistant to atherosclerosis. Our findings suggest that veins may possess mediators, such as PAP and TSPs, which serve as a natural defense against inflammationbased diseases.

\section{Limitations}

There are several limitations to this study that must be recognized. First, the whole blood vessel (all layers) was used in these experiments. The vena cava has an extensive adventitia and all cell types present in this layer are not recognized. Thus, it is difficult to assign any one cell type the differences observed in this study. Second, we used a large artery and vein as opposed to small veins and arteries, as can be found in the mesenteric bed. These smaller vessels are largely responsible for capacitance and total peripheral resistance, respectively, and we cannot state whether our findings in the large vessels apply to the smaller vessels. One might argue the smaller vessels are more physiologically relevant, but the vena cava and aorta serve the important function of providing venous re- 
turn and directly handling the full brunt of cardiac output, respectively. Finally, it would be ideal to have Western analyses for quantitative expression of the proteins studied herein, but this has proven difficult for the TSPs. Native TSPs are approximately $400-450 \mathrm{kDa}$ in size, and handling these proteins such that they remain intact has been difficult. Thus, it will take more care and time to perform such experiments, and the present study represents a first step.

We have just touched the surface of the results that were generated in this robust gene array study. If one searches using the phrase 'inflammatory response' within Gene Sifter ${ }^{\circledR}$, other proteins outside the ones discussed are listed. For example, the aorta possesses greater expression (approx. 3-fold) of secreted phosphoprotein 1 (also known as osteopontin) and bone morphogenetic protein 6, both proteins of which have been positively implicated in the pathology of cardiovascular disease [60, $61]$. We have not followed up on these differences so as to focus on TSPs and PAP. Thus, our investigation into PAP and TSPs is but one level of investigation into differences in genetic expression between veins and arteries, and these findings lead us to the important future mechanistic experiments of testing whether removal of PAP1 or TSPs permits the vein to respond, as an artery does, to an inflammatory challenge.

In summary, these findings suggest that there are numerous differences in arterial versus venous gene expression. Increased mRNA and protein expression for the anti-inflammatory protein PAP1 and the anti-apoptotic proteins TSPs suggest a basic difference in the native defense possessed by the vena cava compared to the aorta.

\section{Acknowledgment}

This work was supported by NHLBI PO1 HL70687.

\section{References}

1 Chobanian AV, Bakris GL, Black HR, Cushman WC, Green LA, Izzo JL Jr, Jones DW, Materson BJ, Oparil S, Wright JT Jr, Roccella EJ: The Seventh Report of the Joint National Committee on Prevention, Detection, Evaluation, and Treatment of High Blood Pressure: the JNC 7 report. JAMA 2003;289: 2560-2572.

-2 Martin DS, Rodrigo MC, Appelt CW: Venous tone in the developmental stages of spontaneous hypertension. Hypertension 1998:31:139-144.

3 Pan YJ, Young DB: Experimental aldosterone hypertension in the dog. Hypertension 1982;4:279-287.

-4 Yamamoto J, Trippodo NC, MacPhee AA, Frohlich ED: Decreased total venous capacity in Goldblatt hypertensive rats. Am J Physiol 1981;240:H487-H492.

5 Ricksten SE, Yao T, Thoren P: Peripheral and central vascular compliances in conscious normotensive and spontaneously hypertensive rats. Acta Physiol Scand 1981;112:169177.

-6 Safar ME, London GM: Arterial and venous compliance in sustained essential hypertension. Hypertension 1987; 10:133-139.

7 Nyhof RA, Laine GA, Meininger GA, Granger HJ: Splanchnic circulation in hypertension. Fed Proc 1983;42:1690-1693.

$\checkmark 8$ London GM, Safar ME, Weiss YA, Simon CA: Total effective compliance of the vascular bed in essential hypertension. Am Heart J 1978;95:325-330.
\9 Schmieder RE, Schobel HP, Messerli FH: Central blood volume: a determinant of early cardiac adaptation in arterial hypertension? J Am Coll Cardiol 1995;26:1692-1698.

10 Swales JD: Textbook of Hypertension. Oxford, Blackwell Scientific Publications, 1994.

-11 Adams RH: Molecular control of arterial-venous blood vessel identity. J Anat 2003;202: 105-112.

12 Egea J, Klein R: Bidirectional Eph-ephrin signaling during axon guidance. Trends Cell Biol 2007; 17:230-238.

13 Eichmann A, Yuan L, Moyon D, Lenoble F, Pardanaud L, Breant C: Vascular development: from precursor cells to branched arterial and venous networks. Int J Dev Biol 2005;49:259-267.

14 Harvey NL, Oliver G: Choose your fate: artery, vein or lymphatic vessel? Curr Opin Genet Dev 2004;14:499-505.

15 Hofmann JJ, Iruela-Arispe ML: Notch signaling in blood vessels: who is talking to whom about what? Circ Res 2007;100:15561568.

16 Kuijper S, Turner CJ, Adams RH: Regulation of angiogenesis by Eph-ephrin interactions. Trends Cardiovasc Med 2007;17:145-151.

17 Lanner F, Sohl M, Farnebo F: Functional arterial and venous fate is determined by graded VEGF signaling and notch status during embryonic stem cell differentiation. Arterioscler Thromb Vasc Biol 2007;27:487-493.
Lawson ND, Scheer N, Pham VN, Kim CH, Chitnis AB, Campos-Ortega JA, Weinstein $\mathrm{BM}$ : Notch signaling is required for arterialvenous differentiation during embryonic vascular development. Development 2001; 128:3675-3683.

19 Yamashita JK: Differentiation of arterial, venous, and lymphatic endothelial cells from vascular progenitors. Trends Cardiovasc Med 2007;17:59-63.

20 Rozen S, Skaletsky H: Primer3 on the WWW for general users and for biologist programmers. Methods Mol Biol 2000;132: 365-386.

21 Edgar R, Domrachev M, Lash AE: Gene Expression Omnibus: NCBI gene expression and hybridization array data repository. $\mathrm{Nu}$ cleic Acids Res 2002;30:207-210.

22 Katsumata N, Chakraborty C, Myal Y, Schroedter IC, Murphy LJ, Shiu RP, Friesen HG: Molecular cloning and expression of peptide 23, a growth hormone-releasing hormone-inducible pituitary protein. Endocrinology 1995;136:1332-1339.

23 Closa D, Motoo Y, Iovanna JL: Pancreatitisassociated protein: from a lectin to an antiinflammatory cytokine. World J Gastroenterol 2007;13:170-174

24 Folch-Puy E, Granell S, Dagorn JC, Iovanna JL, Closa D: Pancreatitis-associated protein I suppresses NF- $\mathrm{B}$ activation through a JAK/STAT-mediated mechanism in epithelial cells. J Immunol 2006;176:3774-3779. 
25 Lin YY, Viterbo D, Mueller CM, Stanek AE, Smith-Norowitz T, Drew H, Wadgaonkar R, Zenilman ME, Bluth MH: Small-interference RNA gene knockdown of pancreatitisassociated proteins in rat acute pancreatitis. Pancreas 2008;36:402-410.

-26 Ortiz EM, Dusetti NJ, Vasseur S, Malka D, Bodeker H, Dagorn JC, Iovanna JL: The pancreatitis-associated protein is induced by free radicals in AR4-2J cells and confers cell resistance to apoptosis. Gastroenterology 1998;114:808-816.

27 Adams JC, Lawler J: The thrombospondins. Int J Biochem Cell Biol 2004;36:961-968.

-28 Lee NV, Sato M, Annis DS, Loo JA, Wu L, Mosher DF, Iruela-Arispe ML: ADAMTS1 mediates the release of antiangiogenic polypeptides from TSP1 and 2. EMBO J 2006;25: 5270-5283.

-29 Good DJ, Polverini PJ, Rastinejad F, Le Beau MM, Lemons RS, Frazier WA, Bouck NP: A tumor suppressor-dependent inhibitor of angiogenesis is immunologically and functionally indistinguishable from a fragment of thrombospondin. Proc Natl Acad Sci USA 1990;87:6624-6628.

30 Chatila K, Ren G, Xia Y, Huebener P, Bujak $M$, Frangogiannis NG: The role of the thrombospondins in healing myocardial infarcts. Cardiovasc Hematol Agents Med Chem 2007;5:21-27.

-31 Daniel C, Amann K, Hohenstein B, Bornstein P, Hugo C: Thrombospondin 2 functions as an endogenous regulator of angiogenesis and inflammation in experimental glomerulonephritis in mice. J Am Soc Nephrol 2007;18:788-798.

- 32 Hogg PJ, Owensby DA, Mosher DF, Misenheimer TM, Chesterman CN: Thrombospondin is a tight-binding competitive inhibitor of neutrophil elastase. J Biol Chem 1993;268:7139-7146.

- 33 Kuznetsova SA, Issa P, Perruccio EM, Zeng B, Sipes JM, Ward Y, Seyfried NT, Fielder HL, Day AJ, Wight TN, Roberts DD: Versican-thrombospondin-1 binding in vitro and colocalization in microfibrils induced by inflammation on vascular smooth muscle cells. J Cell Sci 2006;119:4499-4509.

34 Lamy L, Foussat A, Brown EJ, Bornstein P, Ticchioni M, Bernard A: Interactions between CD47 and thrombospondin reduce inflammation. J Immunol 2007; 178:59305939.

- 35 Lawler J: Thrombospondin-1 as an endogenous inhibitor of angiogenesis and tumor growth. J Cell Mol Med 2002;6:1-12.

-36 Lawler J, Detmar M: Tumor progression: the effects of thrombospondin-1 and -2. Int J Biochem Cell Biol 2004;36:1038-1045.

-37 Park YW, Kang YM, Butterfield J, Detmar M, Goronzy JJ, Weyand CM: Thrombospondin 2 functions as an endogenous regulator of angiogenesis and inflammation in rheumatoid arthritis. Am J Pathol 2004; 165: 2087-2098.
8 Adams LD, Geary RL, McManus B, Schwartz SM: A comparison of aorta and vena cava medial message expression by cDNA array analysis identifies a set of 68 consistently differentially expressed genes, all in aortic media. Circ Res 2000;87:623-631.

39 Shin D, Anderson DJ: Isolation of arterialspecific genes by subtractive hybridization reveals molecular heterogeneity among arterial endothelial cells. Dev Dyn 2005;233: 1589-1604.

40 Deng DX, Spin JM, Tsalenko A, Vailaya A, Ben-Dor A, Yakhini Z, Tsao P, Bruhn L, Quertermous T: Molecular signatures determining coronary artery and saphenous vein smooth muscle cell phenotypes: distinct responses to stimuli. Arterioscler Thromb Vasc Biol 2006;26:1058-1065.

41 Deng DX, Tsalenko A, Vailaya A, Ben-Dor A, Kundu R, Estay I, Tabibiazar R, Kincaid R, Yakhini Z, Bruhn L, Quertermous T: Differences in vascular bed disease susceptibility reflect differences in gene expression response to atherogenic stimuli. Circ Res 2006; 98:200-208.

42 Payeli SK, Latini R, Gebhard C, Patrignani A, Wagner U, Luscher TF, Tanner FC: Prothrombotic gene expression profile in vascular smooth muscle cells of human saphenous vein, but not internal mammary artery. Arterioscler Thromb Vasc Biol 2008;28:705710.

43 Mecha Disassa N, Styp-Rekowska B, Hinz B, Da Silva-Azevedo L, Pries AR, Zakrzewicz A: Differential expression of VEGFA, TIE2, and ANG2 but not ADAMTS1 in rat mesenteric microvascular arteries and veins. Physiol Res 2008, Epub ahead of print

44 Callera GE, Montezano AC, Touyz RM, Zorn TM, Carvalho MH, Fortes ZB, Nigro D, Schiffrin EL, Tostes RC: ETA receptor mediates altered leukocyte-endothelial cell interaction and adhesion molecules expression in DOCA-salt rats. Hypertension 2004; 43:872-879

45 Guzik TJ, Mangalat D, Korbut R: Adipocytokines - novel link between inflammation and vascular function? J Physiol Pharmacol 2006;57:505-528.

46 Henke N, Schmidt-Ullrich R, Dechend R, Park JK, Qadri F, Wellner M, Obst M, Gross V, Dietz R, Luft FC, Scheidereit C, Muller DN: Vascular endothelial cell-specific NF$\kappa \mathrm{B}$ suppression attenuates hypertension-induced renal damage. Circ Res 2007;101:268276.

-47 Horstman LL, Jy W, Jimenez JJ, Ahn YS: Endothelial microparticles as markers of endothelial dysfunction. Front Biosci 2004;9: 1118-1135.

48 Kalogeris TJ, Kevil CG, Laroux FS, Coe LL, Phifer TJ, Alexander JS: Differential monocyte adhesion and adhesion molecule expression in venous and arterial endothelial cells. Am J Physiol 1999;276:L9-L19.
49 Ley K, Gaehtgens P: Endothelial, not hemodynamic, differences are responsible for preferential leukocyte rolling in rat mesenteric venules. Circ Res 1991;69:1034-1041.

-50 Kevil CG, Okayama N, Trocha SD, Kalogeris TJ, Coe LL, Specian RD, Davis CP, Alexander JS: Expression of zonula occludens and adherens junctional proteins in human venous and arterial endothelial cells: role of occludin in endothelial solute barriers. Microcirculation 1998;5:197-210.

51 Watts SW, Rondelli C, Thakali K, Li X, Uhal B, Pervaiz MH, Watson RE, Fink GD: Morphological and biochemical characterization of remodeling in aorta and vena cava of DOCA-salt hypertensive rats. Am J Physiol Heart Circ Physiol 2007;292:H2438-H2448.

- 52 Deatrick KB, Eliason JL, Lynch EM, Moore AJ, Dewyer NA, Varma MR, Pearce CG, Upchurch GR, Wakefield TW, Henke PK: Vein wall remodeling after deep vein thrombosis involves matrix metalloproteinases and late fibrosis in a mouse model. J Vasc Surg 2005; 42:140-148.

-53 Gusic RJ, Myung R, Petko M, Gaynor JW, Gooch KJ: Shear stress and pressure modulate saphenous vein remodeling ex vivo. J Biomech 2005;38:1760-1769.

54 Pascarella L, Penn A, Schmid-Schonbein GW: Venous hypertension and the inflammatory cascade: major manifestations and trigger mechanisms. Angiology 2005;56 (suppl 1):S3-S10.

55 Pascarella L, Schmid-Schonbein GW, Bergan J: An animal model of venous hypertension: the role of inflammation in venous valve failure. J Vasc Surg 2005;41:303-311.

- 56 Takase S, Pascarella L, Bergan JJ, SchmidSchonbein GW: Hypertension-induced venous valve remodeling. J Vasc Surg 2004;39: 1329-1334.

57 Henke PK, Varma MR, Deatrick KB, Dewyer NA, Lynch EM, Moore AJ, Dubay DA, Sukheepod P, Pearce CG, Upchurch GR Jr, Kunkel SL, Franz MG, Wakefield TW: Neutrophils modulate post-thrombotic vein wall remodeling but not thrombus neovascularization. Thromb Haemost 2006;95:272-281.

58 Schachner T: Pharmacologic inhibition of vein graft neointimal hyperplasia. J Thorac Cardiovasc Surg 2006;131:1065-1072.

59 Schachner T, Laufer G, Bonatti J: In vivo (animal) models of vein graft disease. Eur J Cardiothorac Surg 2006;30:451-463.

60 Scatena M, Liaw L, Giachelli CM: Osteopontin: a multifunctional molecule regulating chronic inflammation and vascular disease. Arterioscler Thromb Vasc Biol 2007;27: 2302-2309.

-61 Sorescu GP, Sykes M, Weiss D, Platt MO, Saha A, Hwang J, Boyd N, Boo YC, Vega JD, Taylor WR, Jo H: Bone morphogenic protein 4 produced in endothelial cells by oscillatory shear stress stimulates an inflammatory response. J Biol Chem 2003;278:31128-31135. 